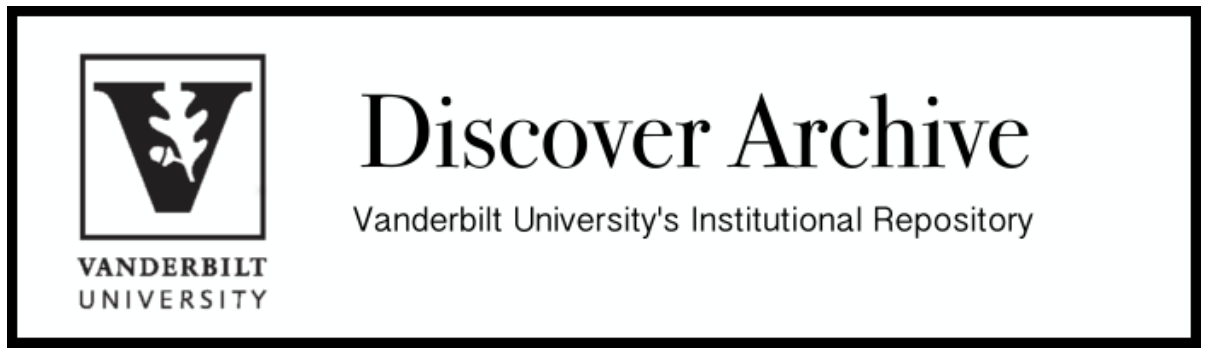

This work was originally published as: Margaret M. Blair and Lynn A. Stout, Specific Investment and Corporate Law - 7 European Business Organization Law Review (2006). 
UCLA School of Law

Law $\mathcal{E}$ Economics Research Paper Series

Working Paper Number 05-30

Vanderbilt University Law School

Law and Economics Research Paper Series

Working Paper Number 05-31

\title{
SPECIFIC INVESTMENT AND CORPORATE LAW
}

\author{
LYNN A. STOUT \\ UCLA School of Law \\ and \\ MARGARET M. BLAiR \\ Vanderbilt University School of Law
}

European Business Organization Law Review, Forthcoming

This paper may be downloaded without charge at:

The Social Science Research Network Electronic Paper Collection

http://ssm.com/abstract $=869010$ 


\title{
Specific Investment And Corporate Law
}

\author{
By \\ Margaret M. Blair and Lynn A. Stout* \\ Forthcoming European Business Organization Law Review
}

\begin{abstract}
At the close of the twentieth century, U.S. corporate scholarship was dominated by a principal-agent paradigm that assumed that shareholders were the principals or sole residual claimants in public corporations, and also assumed that corporate directors were the shareholders' agents. This approach led many corporate scholars to assume that the proper purpose of the corporation was to maximize shareholder wealth and that the chief economic problem of interest in corporate law was the "agency cost" problem of getting corporate directors to focus on this goal.
\end{abstract}

There are basic aspects of U.S. corporate law, however, that the principal-agent model cannot explain. These include directors' extensive and sui generis legal powers; the fact that directors control dividends; the device of legal personality; and the open-ended rules of corporate purpose. These corporate law "anomalies" have prompted contemporary economic and legal scholars to begin to move beyond a focus on agency costs and to pay attention to a second economic problem that arises in public corporations: the problem of protecting specific investment. When corporate production requires more than one individual or group to make specific investments, problems of intrafirm opportunism arise if shareholders try to exploit each other's specific investments or try to exploit the specific investments of creditors, employees, customers, and other groups. Board governance, while worsening agency costs, may provide a second-best solution to such intrafirm rent-seeking. This perspective explains many important corporate law anomalies that cannot be explained by the principal agent model.

It also suggests a pressing need to revisit conventional notions of corporate purpose. Focusing on the problem of specific investment suggests that the proper purpose of the public corporation is not maximizing shareholder wealth, but promoting long-term, value-creating economic production under conditions of complexity and uncertainty, in a fashion that provides surplus benefits not only to shareholders but to other groups that make specific investments in corporations as well. This corporate objective is difficult to measure, much less maximize. Nevertheless, it may provide a better gauge of good corporate governance than the simplistic rubric of shareholder wealth.

\footnotetext{
* Margaret M. Blair is Professor of Law at the Vanderbilt University Law School; Lynn A. Stout is Professor of Law at the UCLA School of Law and Principal Investigator for the UCLA-Sloan Research Program on Business Organizations. Much of this essay has been extracted from a longer article written in honor of Dean Robert Clark, Specific Investment: Explaining Anomalies in Corporate Law, _ J. Corp. L. (forthcoming 2006). An earlier version was presented at ADD CITE; the authors are grateful to participants in that workshop for their helpful insights and suggestions.
} 


\title{
Specific Investment And Corporate Law
}

By

\author{
Margaret M. Blair and Lynn A. Stout
}

\section{Introduction: Kuhn and Corporate Law}

What is a business corporation? What purposes does and should it serve? These questions have been raised repeatedly by legal scholars, practitioners, and policy-makers for at least the last 150 years. Each generation has struggled to find acceptable answers.

In the last decades of the twentieth century, corporate theory has been dominated by an approach to these questions that can be called the principal-agent model. ${ }^{1}$ According to this model, shareholders are the principals or ultimate "owners" of corporations. Directors are agents for the shareholders and, as such, should be subject to shareholder control. Corporations are run well when directors run them according to a "shareholder primacy" norm that requires directors to maximize shareholder wealth. When directors fail to do this, inefficient "agency costs" result.

It is difficult to overstate the influence the principal-agent model has had on modern business thinking. This is especially true in the United States, where shareholder primacy has for years largely crowded out other notions of corporate purpose. Yet a new generation of legal and economic scholars has begun to question the principal-agent model as the best way to understand corporate law and to propose alternatives. After decades of intellectual hegemony, conventional shareholder primacy seems poised for decline.

\footnotetext{
${ }^{1}$ Henry Hansmann \& Reinier Kraakman, The End of History in Corporate Law, 89 Geo L. J. 439, 440-41 (2001) (arguing that academic, business and government elites now agree that "the managers of the corporation should be charged with the obligation to manage the corporation in the interests of its shareholders ... and the market value of the publicly traded corporation's shares is the principal measure of the shareholder's interest”); see also R. Gordon Smith, The Shareholder Primacy Norm, 23 J. Corp. L. 277 (1998).
} 
In this essay we explore why. In particular, we explain that the principal-agent model is vulnerable for the simple reason that it fails to explain many important aspects of corporate law. During the heyday of shareholder primacy, academics tended to react to these legal "anomalies" either by glossing over them, or by arguing that corporate law needed "reform" to bring it closer to the shareholder primacy ideal. Today many scholars are trying a different approach. Rather than trying to make corporate law fit the principal-agent model, they are searching for new models that better fit corporate law.

In the process, they are providing an object lesson in the nature of intellectual progress described in Thomas Kuhn's classic and much-cited The Structure of Scientific Revolutions. ${ }^{2}$ As Kuhn observed, the world bombards us with information that is often puzzling, ambiguous, incomplete, even apparently contradictory. Somehow we must do our best to find meaning in the barrage of data. Kuhn argued that we make sense of the world by developing mental models about the way it works, theories about how certain causes lead to certain effects. At different times, for example, people have believed that infectious diseases were caused by witches, by night air, and by microbes.

Kuhn labeled these mental models "paradigms.” According to Kuhn, once a society or culture embraces a particular paradigm as a way to explain a particular phenomenon, most of the individuals in that society will cling to the paradigm with remarkable tenacity. They will believe the paradigm to be a true and accurate description of the world even in the face of significant anomalies—empirical phenomena that cannot be explained by, or that even seem inconsistent with, the paradigm. Rather than reconsidering the paradigm, they overlook, dismiss as unimportant, or attempt to explain away the anomalies. Yet at some point, the anomalies may become so obvious and so troubling that a few individuals begin studying them. These

${ }^{2}$ Thomas Kuhn, The Structure of Scientific Revolutions (3d. ed., 1996). 
individuals may develop a new theory that explains the anomalies, an alternate paradigm that does a better job of predicting what we see in the world. Often their ideas will be resisted by those who follow the original paradigm. Yet if the new paradigm does a better job than the old one of predicting what we actually observe, it will eventually win hearts and minds, and be accepted as correct. The old paradigm will come to be viewed as incomplete and outdated, a partial explanation at best.

During the 16th century, for example, many Europeans believed the sun revolved around the earth. This theory did a nice job of explaining why the sun appeared to rise in the East each morning and set over the western horizon each evening, but it could not explain the movements of the planets in the night sky. The Italian astronomer Galileo advanced an alternative model of a heliocentric universe that predicted not only the sun's movements but those of the planets as well. Not everyone appreciated Galileo's ideas at the time (he was investigated by the Inquisition and placed under house arrest for heresy), but today most educated people believe the earth does indeed circle around the sun. ${ }^{3}$

For most of the last three decades, corporate scholarship has been dominated by the powerful paradigm called the principal-agent model. This paradigm teaches that the concept of a corporate personality is not something to be taken seriously. Rather, a corporation is best understood as a nexus of private contracts. Chief among these contracts is the contract between the shareholders of the firm (often described as the "principals" or "owners" of the firm) and the directors and executive officers (usually described as the shareholders' "agents”). The principal-

\footnotetext{
${ }^{3}$ Kuhn's book suggests humankind is a long way from completely understanding the universe, and in this sense all paradigms are to some extent social constructions and none are entirely "correct.” Kuhn nevertheless clearly believes some paradigms are better than others at predicting real phenomena. Microbes are a better explanation for disease than witches, and it is more correct to say the earth revolves around the sun than vice versa.
} 
agent model envisions this contract as an agreement that the directors and executives will run the firm in a fashion that maximizes the shareholders' wealth.

The principal-agent model maintained a firm grip on the corporate law literature throughout the 1980s and 1990s, and many influential academics still employ the model today. Yet even as a generation of experts embraced the principal-agent model, they could not help but observe, often with frustration, how many fundamental aspects of corporate law seemed inconsistent with the approach. Part I of this Essay explores four of these fundamental corporate law anomalies: (1) corporate law does not grant shareholder the legal rights of principals nor burden directors with the legal obligations of agents; (2) corporate law does not treat shareholders of solvent firms as sole residual claimants; (3) far from being an empty fiction, legal personality is a key feature of the corporate form; and (4) corporate law does not impose any obligation on directors to maximize shareholder wealth.

Despite these obvious inconsistencies between theory and practice, until recently most corporate experts continued to accept the principal-agent model and to assume, consistent with this approach, that shareholder wealth maximization should be the corporate goal. ${ }^{4}$ This sometimes-uneasy embrace of the shareholder primacy norm illustrates another of Kuhn's observations: intellectual progress often must await the arrival of new tools and technologies. The hypothesis that infectious diseases are caused by microbes rather than witches or night air, for example, could not gain widespread acceptance until the invention of the microscope, a technology that confirmed the existence of microbes by allowing scientists to observe them directly.

\footnotetext{
${ }^{4}$ See, e.g., Robert C. Clark, Corporate Law 17 (1986) (noting that U.S. corporate law fails to require directors to maximize shareholder wealth but stating this ought to be the corporate purpose).
} 
Similarly, corporate law scholars until recently lacked the theoretical tools necessary to explain the anomalies that are so obvious to informed observers. The principal-agent literature was the primary intellectual tool available to business scholars in the 1980s and 1990s, and they naturally tended to apply it liberally to many aspects of the corporate form. As the saying goes, when your only tool is a hammer, every problem tends to look like a nail.

More recently, however, theorists have begun to study and to write on a second economic problem that may be even more important to understanding the corporate form. This is the problem of protecting and encouraging "specific" investments—specialized resources that achieve their highest value only when used in a particular process or project. The developing literature on the difficulties associated with fostering specific investment has created new theoretical tools that offer fresh insights into old puzzles in corporate law.

Part II of this essay explores how, in particular, two new ideas being developed on specific investment—work on team production and the emerging concept of capital lock-in (work we have contributed to elsewhere, both individually and together)--shed light on important features of corporate law that contradict the principal-agent model. With these new intellectual tools, modern corporate scholars are poised to take up where a previous generation of necessity left off. In the process, they will need to revisit the question of the proper social and economic role of business corporations.

\section{The Principal-Agent Model and the Structure of Corporate Law}

To understand the origins of the principal-agent paradigm of the corporation, we need to go back to a famous article published in 1976 by finance theorists Michael Jensen and William 
Meckling. ${ }^{5}$ In Theory of the Firm, Jensen and Meckling argued that a firm should not be characterized as an entity that has its own goals and intentions (e.g., "maximize profits"). Instead, a firm should be regarded as a nexus of contracts through which human actors -who do have goals and intentions--interact with each other. In particular, Jensen and Meckling said the most important contractual relationship in the firm was that between the primary investors or "owners" of the business, and the professional "managers" whom the owners hire to carry on the business on their behalf. (As this brief description suggests, Jensen and Meckling's analysis from its inception failed to reflect at least one reality of the modern corporation. As students who take corporate law quickly learn, corporations are not run by generic "managers." Rather, the law divides the task of running corporations among three categories of corporate participants -- directors, officers, and shareholders - with each of these groups facing a different set of legal rights and responsibilities.)

The Jensen and Meckling article built on an important literature in economics dealing with problems that arise when firms are run not by their owners, but by professionals whom the owners hire. ${ }^{6}$ In particular, Jensen and Meckling suggested that whenever one person (a "principal”) hires another (an "agent”) to act on the principal's behalf, there will inevitably be "agency costs" that arise because (1) the agent might not always make the same choices the principal would, and (2) it is costly for the principal to try to monitor and control the agent to prevent this. The Jensen and Meckling approach highlighted the slippage between the principal's desires and the agent's actual choices, and the trade-off principals face between suffering the slippage or trying to control it through costly monitoring or incentive arrangements.

\footnotetext{
${ }^{5}$ Michael C. Jensen \& William H. Meckling, Theory of the Firm: Managerial Behavior, Agency Costs, and Ownership Structure, 3 J. Fin. Econ., 4, 305-360 (1976).

${ }^{6}$ See e.g., Oliver Williamson, The Economics of Discretionary Behavior: Managerial Objectives in a Theory of the Firm (1964), Marris, The Economic.Theory of Managerial Capitalism (1964).
} 
The agency cost model described the structure of certain types of contracts, but not the structure of firms in general, nor the structure of the unique type of firm called a public corporation. Nevertheless, many corporate scholars embraced their approach and, in applying it to corporations, concluded that the shareholders must be the "principals" and directors and officers must be the shareholders' "agents." This idea had enormous appeal for a generation of business scholars who were confronted during the 1970s and early 1980s with the pressing question of what corporate law should require of executives and directors confronted with the newly-popular practice of unsolicited tender offers.

Economist Robin Marris had argued in the early 1960s that, even though in theory corporate "managers" might be tempted to let their personal concerns interfere with shareholder wealth maximization, if managers failed to maximize the value of a firm's shares in practice, an outside investor could make money by buying up the corporation's shares at a discount and replacing the managers or compelling them to maximize value. ${ }^{7}$ Very soon after, legal scholar Henry Manne proposed a similar idea, arguing that corporate managers would be driven to maximize share value by what he called "the market for corporate control."»

This argument, combined with the Jensen and Meckling theoretical framework, was seized upon by other corporate scholars as a rationale for arguing that corporate law ought to respond to the development of the hostile tender offer with rules that prohibited directors from resisting such offers. A substantial literature soon appeared arguing that directors, as "agents" for the corporation's shareholders, ought to have a legal duty to manage the corporation to

\footnotetext{
7 See Marris, supra note 6.

${ }^{8}$ Henry G. Manne, Mergers and the Market for Corporate Control, 73 J. P. Econ., 110-120 (1965).
} 
maximize share value, including acquiescing to any takeover that offered an immediate premium over the current market price of the shares. ${ }^{9}$

This example illustrates how enormously appealing the principal-agent model was to corporate scholars during the 1970s and early 1980s, when they were eager to find an approach that would allow them to make definitive policy judgments and recommendations about hostile tender offers. Nevertheless, there remained at least one glaring problem with simultaneously arguing that a corporation should be regarded as a nexus of contracts, and arguing that corporate law should require corporate managers to act on behalf of the shareholders who "owned" the firm. The problem was that the nexus metaphor did not support the notion that the corporation was something that could be "owned."

Legal scholars Easterbrook and Fischel, two leading advocates of the "law and economics” movement, soon fixed that problem. In a series of articles in the early 1980s they argued that while it did not make sense to speak of a nexus as having an owner, it was still conceptually useful and normatively correct to treat corporate directors and officers as shareholders' agents. ${ }^{10}$ Easterbrook and Fischel asserted that when the various groups that participate in corporate production come together (groups that include, among others, creditors,

\footnotetext{
${ }^{9}$ See e.g., Frank H. Easterbrook \& Daniel R. Fischel, The Proper Role of A Target’s Management in Responding to a Tender Offer, 94 Harv. L. Rev. 1161 (1981); Ronald J. Gilson, A Structural Approach to Corporations: The Case Against Defensive Tactics in Tender Offers, 33 Stan. L. Rev. 5, 819-891 (1981).

The leap from viewing managers and directors as shareholders' agents to concluding that managers and directors must stand willing to sell out the corporation to a highest bidder requires one more assumption commonly accepted by proponents of law and economics. This additional assumption is that securities markets are both informationally and allocationally efficient, so that the market price of a company's shares reflects their "fundamental" economic value. Although during the 1980s the idea of fundamental value efficiency enjoyed widespread support, in recent years it has been subject to both theoretical and empirical challenge, and many finance economists no longer accept it. See generally Lynn A. Stout, The Mechanisms of Market Inefficiency: An Introduction to the New Finance, 28 J. Corp. L. 633 (2003).

${ }^{10}$ See, e.g., Frank H. Easterbrook \& Daniel R. Fischel, Corporate Control Transactions, 91 Yale L. J. 698, 700-02 (1982); Frank H. Easterbrook \& Daniel R. Fischel, Voting in Corporate Law, 26 J. L \& Econ. 395, 395-427 (1983); Frank H. Easterbrook \& Daniel R. Fischel, Two Agency-Cost Explanations of Dividends, 74 Am. Econ. Rev. 650 (1984). The ideas in these articles were later brought together in an influential book, Frank H. Easterbrook \& Daniel R. Fischel, The Economic Structure of Corporate Law (1991).
} 
suppliers, executives, employees, and shareholders) to interact through the nexus of contracts called "the corporation," only one of these groups—-the shareholders—contracts to be the firm's residual claimant. ${ }^{11}$ All other participants enter contracts that require them to be paid first, before the common stockholders can be paid. Since shareholders only get paid if the corporation produces a surplus over and above all its contractual obligations (according to the theory), shareholders have a strong incentive to see that this surplus, the "profit" from the enterprise, is maximized. Thus, as holders of both residual claim rights and residual control rights, shareholders play a role similar to that played by the owner of an individual proprietorship, and it remains reasonable to refer to shareholders as "owners" even though technically no one can own a nexus. $^{12}$

The end result was the paradigm we call the principal-agent model of the corporation, an elegant theoretical framework for thinking about what corporate law should look like and what purposes it should serve. This framework was quickly adopted by mainstream scholars in the corporate law community, and it was in the context of this framework that a generation of theorists examined the corporate issues of the day, including the development of antitakeover defenses like the staggered board and "poison pill," the structure and enforcement of directors' fiduciary duties, the best way to compensate directors and executives, and the nature and extent of shareholders' voting rights. Nevertheless, despite the conceptual beauty of the principal-agent framework, these attempts to apply the principal-agent model to the practice of corporate law

\footnotetext{
${ }^{11}$ See id. at 11. Clearly most corporate participants do not actually bargain in this way, so the argument was an "as if” argument of the type legitimized by economist Milton Friedman when he claimed that it is acceptable to argue that economic actors "optimize" if the outcomes of their choices correspond to those that would obtain if in fact economic actors had consciously optimized. Milton Friedman, The Methodology of Positive Economics, in Essays in Positive Economics 3-16, 30-43 (1966). Even if shareholders do not literally bargain to be residual claimants, the argument goes, if in fact we see shareholders play this role, the result is the same.

${ }^{12}$ See, Easterbrook \& Fischel, Economic Structure, supra note 10 at 36-39, 185-191; see also Easterbrook \& Fischel, Voting, supra note 10 at 396 ("shareholders are no more 'owners'” of the firm than are bondholders, other creditors, and employees (including managers) who devote specialized resources to the enterprise”).
} 
highlighted how the model did not fit quite right. Despite decades of repeated calls for "reform," the rules of corporate law and the realities of business practice stubbornly remained at odds with the principal-agent framework.

\section{A. Directors Are Not “Agents.”}

One of the most important ways in which corporate law departs from the predictions of the principal-agent model is that, unlike traditional principals, shareholders in publicly-traded corporations have little control over who the directors are and no direct control over what the directors do. The rules of agency law provide that an agent owes her principal a "duty of obedience.” Yet U.S. corporate law does not require directors to follow shareholder mandates in any way. To the extent shareholders exercise any influence at all, it is only through two indirect and very dilute sources of power.

The first source of power is shareholders' very limited voting rights. Corporate law gives shareholders a right to vote on a slate of directors that has normally been selected by the existing directors (in extraordinary circumstances and at great personal cost, a disgruntled shareholder can propose an alternative slate). Once elected, it is the directors and not the shareholders who control the corporation and select and control the executive officers who run the firm on a dayto-day basis. Neither directors nor executives are required to do what the shareholders request. As a result it is directors, and not shareholders, who enjoy the legal right to set general business strategy and to control such key matters as the selection of executives and other employees, ${ }^{13}$ the declaration and distribution of dividends, ${ }^{14}$ the setting of directors' fees and employees’

\footnotetext{
${ }^{13}$ Clark, supra note 4, at 105-106. See, e.g., Auer v. Dressel, 118 N.E. 2d 590, 593 (N.Y. 1954)(holding that directors have no legal obligation to respond to shareholder resolution demanding reinstatement of dismissed officer).

${ }^{14}$ Clark, supra note 4, at 106, 594.
} 
salaries, ${ }^{15}$ and the decision to use corporate assets or earnings to benefit nonshareholder constituencies like creditors, employees, the local community, or even general philanthropic causes. ${ }^{16}$ Nor do the rules of fiduciary duty constrain directors in such matters. Although the duty of loyalty precludes directors from expropriating corporate assets for themselves, ${ }^{17}$ as long as directors refrain from using their corporate powers to line their own pockets their decisions are protected from shareholder challenge by the doctrine known as the business judgment rule. ${ }^{18}$

The second weak and indirect source of power available to shareholders in a public corporation is their power to sell their shares. Normally the power to sell shares does not offer individual shareholders much protection from director incompetence for the same reason that the power to use emergency exits does not offer much protection to partygoers in a burning nightclub; neither strategy works well when everyone tries to employ it simultaneously. However, as both Marris and Manne pointed out in the 1960s, when shareholders sell en masse to a single buyer, whether an individual or another corporation, that single buyer can overcome the obstacles to collective action that plague dispersed shareholders in public firms and use voting rights to oust a recalcitrant board. The result (to use Manne’s hopeful phrase) is an active “market for corporate control.”

The principal-agent model gained much of its traction in the early 1980s, the peak years of the hostile takeover wars. In the decades since it has become clear that, like shareholders' voting rights, the "market for corporate control" (at least in the United States) gives shareholders

15 Clark, supra note 4, at 106, 191. See, e.g., In Re Disney Derivative Litigation, No. Civ. A. 15452, 2005 WL 2056651 (Del. Ch. August 9, 2005).

${ }^{16}$ Clark, supra note 4, at 105-06, 136-37, 681-82. See, e.g., Credit Lyonnais Bank Nederland, N.V. v. Pathe Communications Corp., Civ. A. No. 12150, 1991 Del. Ch. LEXIS 215 (Del. Ch. Dec. 30, 1991)(upholding board discretion to pursue strategy that favored creditors' interests over shareholder's objections); Shlensky v. Wrigley, 237 N.E.2d 776 (Ill. App. Ct. 1968) )(upholding director discretion to pursue strategy that favored local community over shareholder's objections); Theodora Holding Corp. v. Henderson, 257 A.2d 398 (Del. Ch. 1969)(upholding director discretion to make philanthropic contributions over shareholder's objection).

17 Clark, supra note 4, at 141-42 (discussing duty of loyalty).

18 Id. at 123-129 (discussing business judgment rule). 
only a very weak and indirect source of influence over corporate boards. In particular, the widespread adoption of poison pills, staggered boards, and other antitakeover defenses has made it possible for today's directors to fend off all but the most determined, wealthy, and patient bidders. ${ }^{19}$ Moreover, by the late 1980s, case law and "other constituency" statutes had affirmed directors' discretion to adopt these and similar devices in response to hostile takeovers, including their authority to use defenses to protect nonshareholder interests ${ }^{20}$ and to protect "long run" corporate strategies (with the directors, of course, in charge of selecting the time frame for carrying out those strategies). ${ }^{21}$

Thus U.S. corporate law today retains the same structure it had evolved before the rise of the principal-agent model: directors' legal powers and responsibilities do not resemble those of agents, but rather those of trustees. As corporate law guru and former Dean of the Harvard law school Robert Clark has succinctly articulated, the actual authority structure of the corporation is as follows:

"(1) corporate officers like the president and treasurer are agents of the corporation itself; (2) the board of directors is the ultimate decision-making body of the corporation (and in a sense is the group most appropriately identified with 'the corporation'); (3) directors are not agents of the corporation but are sui generis; (4) neither officers nor directors are agents of the stockholders; but (5) both officers and directors are 'fiduciaries' with respect to the corporation and its stockholders." 22

\footnotetext{
${ }^{19}$ See Lynn A. Stout, The Shareholder As Ulysses: Some Empirical Evidence on Why Investors In Public Corporations Tolerate Board Governance, 152 U. Pa. L., Rev. 667, 694-695 (2003) (discussing lack of active market for control); see also Lucian Arye Bebchuk Bebchuk et al., The Powerful Antitakeover Force of Staggered Boards: Theory, Evidence, and Policy, 54 Stan. L. Rev. 887, 890-91 (2002) (study finding that between 1996 and 2000, no hostile bidders succeeded against firms that had adopted staggered board structure).

${ }^{20}$ See Smith, supra note 1, at 289 (discussing other constituency statutes); Unocal Corp. v. Mesa Petroleum Co., 493 A.2d 946, 955 (Del. 1985)(discussing director discretion to consider interests of creditors, customers, employees, and community).

${ }^{21}$ See Paramount Communications, Inc. v. Time, Inc., 571 A. 2d 1140, 1151-55 (Del. 1989)(discussing directors’ discretion to choose best "long-run" strategy). In an earlier case, the Delaware Surpeme Court had suggested that in limited circumstance directors might be required to maximize share price. See Revlon v. MacAndres \& Forbes Holdings, 506 A. 2d 173, 176 (Del. 1986). Paramount and other subsequent cases make clear that directors can easily avoid being subject to Revlon duties. Stout, supra note 19, at 696.

${ }^{22}$ See Clark, Agency Costs versus Fiduciary Duties, in Principals and Agents: The Structure of Business 55, 56 (John W. Pratt \& Richard J. Zeckhauser eds.)(1985).
} 
This description forthrightly acknowledges what many corporate scholars writing during the last part of the twentieth century tended to gloss over, dismiss as unimportant, or simply refuse to see. The claim that shareholders are "principals" and directors are "agents" contradicts the realities of corporate law. ${ }^{23}$

\section{B. Shareholders Cannot Demand Dividends (And So Cannot Be Sole Residual}

\section{Claimants).}

A second important anomaly of corporate law, closely related to the legal fact that corporate law does not give shareholders the control over corporations associated with the idea of "ownership," is the fact that corporate law also does not grant the shareholders of a corporation that is not in bankruptcy the rights of sole residual claimants. ${ }^{24}$ This economic reality is reflected in the corporate law rules surrounding dividends.

One of the most basic rules of corporate law is that only directors may cause the corporation to declare and pay dividends. ${ }^{25}$ Moreover, they must do this acting as a body-no individual director has the authority to declare dividends by herself. This rule seems to strike a fatal blow to the notion that corporate law treats shareholders as sole residual claimants entitled to every penny of profit left over after the firm’s contractual obligations to other groups have been met. To address this obvious point, corporate scholars defending the principal-agent paradigm typically argue that it still makes sense to view shareholders as the firm's sole residual claimants because, even if a corporation's profits are not paid out in dividends, they are

\footnotetext{
${ }^{23}$ Cf. Clark, supra note 4, at 22 ("the relationship between shareholders and directors is not well described as being between principals and agents.").

24 Nor is it clear shareholders enjoy this status even when the firm is in bankruptcy. Lynn M. PoPucki, The Myth of the Residual Owner, 82 Wash. U. L. Q. 1341, 1343 (2004) (empirical study finding that even in bankruptcy reorganization, "no identifiable, single residual owner class exists").

${ }^{25}$ Clark, supra note 4, at 106, 594
} 
preserved as retained earnings. Thus (the argument goes) retained profits increase the value of the firm, and with it, the market value of the shareholders' equity interest. ${ }^{26}$

The power of the principal-agent paradigm is such that is has led even sophisticated commentators $^{27}$ to overlook the rest of the anomaly--the retaining earnings argument doesn't work for the simple reason that earnings are an accounting concept that directors, and not shareholders, control. Even if a corporation is drowning in a flood of money, it remains up to the directors to decide whether and to what extent shareholders will share in that wealth through either dividends or share price appreciation. This is because directors control dividends under the dividend rules, and also control earnings under the accounting rules. Earnings are nothing more than revenues minus expenses--and it is the directors, and not the shareholders, who determine the corporation's expenses.

The board of a firm that is making a surplus can choose to pass that surplus on to the corporation's shareholders. But it can choose instead to use the corporation's increasing wealth to raise employee salaries, buy the CEO an executive jet, build an on-site childcare center, improve customer service, or make donations to charity and the local community. Economic and legal reality simply does not track the principal agent model. Many different groups are potential "residual claimants" in corporations in the sense that they can share in the surplus created by the activities of the enterprise, including not only shareholders, but also creditors, customers, employees, and the community as well.

\section{C. "Legal Personality" is a Key Feature of Corporations.}

The nexus of contracts approach to the corporation implies that the notion that the corporation is a legal entity is not only a useless idea, but a misleading one--a corporation is only

${ }^{26}$ See id. at 594-602 (discussing Modigliani Miller approach to irrelevance of dividend payouts).

27 See, e.g., Clark, supra note 4 at 594 (stating that directors and not shareholders control dividends) and at 18 (stating that "it is the shareholders who have the claim on the residual value of the enterprise".) 
a web of explicit and implicit agreements among the various groups that participate in "the firm."

This view has led economists and corporate scholars to downplay the importance of corporate personality and even to scoff at the notion that the corporation is an entity in its own right. ${ }^{28}$

Nevertheless, legal personality remains an essential corporate characteristic. Indeed, it may be the most important characteristic to distinguish the corporate form from proprietorships and traditional partnerships. ${ }^{29}$

This is because entity status allows corporations to do something neither proprietorships nor traditional partnerships can easily do: shield the property used in the enterprise from the claims of equity investors, their successors and heirs, and their creditors. ${ }^{30}$ At law, the corporation itself "owns" all assets held in the corporate name. This is more than a mere convenience. It means that an equity investor who needs money cannot raise it by forcing the corporation to return her investment.

As Part II will discuss in greater detail, this ability to "lock in" corporate capital may be vital to understanding the evolution and success of the corporate form. In particular, it allowed public corporations to safely invest in what economists call "specific" assets—infrastructure, machinery, processes, or relationships that are specialized to the enterprise and that would be worth far less if sold on the market for cash than they are worth when used in the firm. ${ }^{31}$

\footnotetext{
${ }^{28}$ See, e.g., Easterbrook \& Fischel, Economic Structure, supra note 10 at 12 (arguing that “[t]he 'personhood' of a corporation is a matter of convenience rather than reality").

29 As late as 1986 the Uniform Partnership Act (UPA), which was the basis of most state law governing partnerships, was ambiguous on the question of whether partnerships had separate entity status. See UPA (1914), Sec. 6(1). The Revised Uniform Partnership Act (1997) clarifies that the default rule is that a partnership formed under the new act is given entity status. See Margaret Blair, Reforming Corporate Governance: What History Can Teach Us, 1 Berkeley Business Law Journal, 1, 1-44, text \& notes 59-61 (discussing this evolution in the law and its implications).

30 See infra text accompanying notes 43-45, 65-67.

${ }^{31}$ Oliver Williamson was among the first economists to explore the significance of investments in specific assets for the allocation of investment returns and the structure of ownership rights in long-term contracts. See e.g., Williamson, Transaction-Cost Economics: The Governance of Contractual Relations, 22 J. L. Econ. 233 (1979). Margaret Blair, Ownership and Control: Rethinking Corporate Governance for the Twenty-first Century 249-271 (1995) highlighted the implications of specific investments in human capital for corporate governance.
} 
Specific investments are often essential to long-term, uncertain, and complex economic projects (building railroads, developing new technologies, creating trusted brand names). Unfortunately, specific investment is easily discouraged when individual investors have a legal right to prematurely withdraw their contributions, and with it, the ability to threaten to withdraw in order to opportunistically "hold up" their fellow investors and extract a larger share of the surplus generated by corporate activity. After investors have pooled their money to build a railroad, for example, it would cause enormous trouble if any of the investors were entitled to demand his or her money back. The corporation's legal personality helps solve this problem by saying, in effect, that the railroad's assets belong not to the investors but to the railroad itself, and that only the railroad's directors--not its shareholders--may decide when to pull capital out of the enterprise to pay dividends, repurchase shares, or for any other purpose.

Incorporation accordingly means that individual equity investors in a public corporation can only get their money back by finding someone else willing to purchase their shares and their interest in the enterprise. Especially before the development of business forms like the limited partnership or limited liability company (LLC), this consequence of legal personality provided a key difference between partnerships and corporations. In traditional partnerships, each partner has the right at any time to withdraw her share of the assets from the firm. ${ }^{32}$ Part II will discuss in greater detail how the corporation's ability to "lock-in” capital through its status as a legal personality may be important to explaining the rise of the corporation in the nineteenth century and the peculiar advantages corporations enjoy in encouraging long-term, complex economic projects.

\footnotetext{
32 See Clark, supra note 4, at 19 ("Rarely do common shareholders in public corporations have a right to force the corporation to buy back their shares. Nor are they able, on their own initiative, to force the company to liquidate and thus pay all the shareholders. Consequently, there is no risk, as there is in a general partnership, that the joint exercise of such a right by a number of investors will kill the enterprise. Corporations. . . . are more likely to preserve the going concern value of large projects.")
} 


\section{Corporate Law Does Not Require Shareholder Wealth Maximization.}

Finally, let us consider one of the most significant anomalies in corporate law to trouble scholars who follow the principal-agent model: the rules of corporate purpose. According to the principal-agent model, the purpose of the corporation is clear. Corporations exist only to maximize profits, and with them, the wealth of the shareholders who are said to be the firm's sole residual claimants. There is one obvious and dramatic problem with this claim, however. There is very little in U.S. corporate law that supports it, and much that cuts against it.

Partnership law defines a partnership as an association for the purpose of earning business profits. $^{33}$ But corporate law does not define the purpose of the corporation beyond restricting it to "lawful" activities. ${ }^{34}$ This means that corporate purpose remains, as a matter of law, an “extremely varied, inclusive, and open-ended” concept. ${ }^{35}$ Nevertheless, having only the principal-agent paradigm to work with, most corporate scholars writing in the waning years of the twentieth century tried to accommodate that perspective. While often recognizing how corporate law did not fit principal-agent analysis, many nevertheless ultimately accepted the idea that corporate directors should, as a normative matter, focus on maximizing value for shareholders. A classic example can be found in Robert Clark’s leading treatise on U.S. corporate law, which states that "[a]lthough corporation statutes do not answer this question explicitly, lawyers, judges, and economists usually assume that the more ultimate purpose of a business corporation is to make profits for its shareholders.”36

\footnotetext{
33 Clark, supra note 4, at 16.

34 See, e.g., Del. Code Ann. Tit. 8, Section 102(a)(3).

35 Clark, supra note 4, at 17; see also id at 678 (noting that "perhaps surprisingly, the state business corporation statutes under which corporations are chartered generally do not say explicitly that the purpose of the business corporation is to make or maximize profits.”)

36 Id. at 17 , emphasis added.
} 
The main case Clark relied on in making this claim was, of course, the old chestnut Dodge v. Ford — a case nearly a century old, from a state unimportant to corporate law (Michigan), dealing with shareholder fiduciary duties in a closely-held (not public) company to boot. ${ }^{37}$ Virtually every corporate scholar who has ever tried to argue that U.S. corporate law follows shareholder primacy has been forced, like Clark, to base his or her argument on the dictum of the antiquated Dodge v. Ford. Yet ample modern case law confirms directors' legal freedom to divert corporate assets and earnings to creditors, employees, customers, the community, and even general charities. ${ }^{38}$ Corporate law also clearly permits directors to require the corporation to obey laws and regulations even when violating the law would be more profitable for shareholders. ${ }^{39}$

This anomaly can be readily dismissed by those who want to dismiss it, because it is easy for corporate directors to (as Clark's treatise puts it) “make the right noises” and claim that actions taken on behalf of nonshareholder constituencies also benefit shareholders "in the long run." ${ }^{40}$ And if the directors themselves fail to advance this claim, it is also easy for a court, or a scholar, simply to advance the claim for them. Nevertheless, the outcome is clear. U.S. corporate law does not follow the principal-agent paradigm on the question of corporate purpose.

\section{Explaining Anomalies: On Specific Investment, Capital Lock-In, and Team Production}

37 Dodge v. Ford Motor Co., 170 N.W. 668 (Mich. 1919).

Contrary to the notion that corporate officers and directors have an enforceable duty to maximize value for shareholders, liability is only very rarely imposed on directors for anything other than breach of the duty of loyalty (that is, using their corporate positions to line their own pockets, a practice which harms not just shareholders but all the groups that participate in firms.) Very few cases impose liability on directors for breach of the duty of care and, curiously, most of those cases were brought on behalf of banks or other financial institutions in situation where directors' supposed lack of care harmed not shareholders but depositors or other creditors. Thompson \& O'Kelley, Corporations and Other Business Associations: Cases and Materials 233-234 (2003). Apparently it is usually the bankruptcy trustee who pursues these cases.

${ }^{38}$ Clark, supra note 4 , at 681-84.

${ }^{39}$ Id. at 686.

${ }^{40}$ Id. at 682. 
As Part I has detailed, there are many important ways in which the structure of U.S corporate law departs from the predictions of the principal-agent model. Although the misfit is obvious and in some cases dramatic, the reasons for the divergence remained unclear to a generation of theorists forced to work in a paradigm that treated common shareholders as the sole residual claimants in corporations. This paradigm in turn reflected legal scholars’ enthusiasm for adapting the economic literature on the principal-agent problem to the institution of the public corporation.

In this Section we suggest that a new paradigm is appearing in corporate law scholarship, one that offers to resolve many of the anomalies discussed in Part II. The new paradigm is emerging because corporate scholars have an intellectual tool to work with that they did not have a generation ago: a developing literature on the economic problem of encouraging and protecting specific investment. In several recent papers, economic and legal scholars (including ourselves, working both alone and together) have investigated how specific investment offers insights into a number of peculiar features of corporations that don’t fit the principal-agent model, including their entity status and their director-dominated governance structure. ${ }^{41}$ This growing literature

\footnotetext{
41 See, e.g., Symposium: Team Production in Business Organizations, 24 J. Corp. L. 743 (1999); Steven A. Bank, A Capital Lock-In Theory of the Corporate Income Tax, 94 Geo. L. Rev. (forthcoming 2005); Margaret M. Blair, Locking In Capital: What Corporate Law Achieved for Business Organizers in the Nineteenth Century, 51 U.C.L.A. L. Rev. 387 (2003); Margaret M. Blair \& Lynn A. Stout, A Team Production Theory of Corporate Law, 85 Va. L. Rev. 247, 275, 278 (1999); Margaret M. Blair \& Lynn A. Stout, Director Accountability and the Mediating Role of the Corporate Board, 79 Wash. U. L. Q. 403 (2001); Harold Demsetz, The Economics of the Business Firm: Seven Critical Commentaries 50-51 (1995); Henry Hansmann \& Reinier Kraakman, The Essential Role of Organizational Law, 110 Yale. L. J. 387 (2000); Peter Kostant, Exit, Voice and Loyalty in the Course of Corporate Governance and Counsel's Changing Role, 28 J. Socio-Econ. 203 (1999); Lynn LoPucki, A Team Production Theory of Bankruptcy Reorganization, 57 Vand. L. Rev. 741 (2004); Lynn A. Stout, Bad and Not-So-Bad Arguments for Shareholder Primacy, 75 S. Cal. L. Rev. 1189 (2002); but see Alan J. Meese, A Team Production Theory of Corporate Law: A Critical Assessment, 43 Wm. \& Mary L. Rev. 1629 (2002); David Millon, New Game Plan or Business as Usual? A Critique of the Team Production Model of Corporate Law, 86 Va. L. Rev. 1001 (2000). Basic corporate law casebooks also have begun to discuss the importance of specific investment and director governance. See, e.g., Robert W. Hamilton \& Jonathan R. Macey, Cases and Materials on Corporations 2225 (9th ed.)(2005) (discussing team production model of corporation); Charles R.T. O’Kelley, Corporations and Other Business Associations 7 (4th ed. 2003)(discussing problem of team-specific investment). Stephen Bainbridge
} 
suggests that the principal-agent model fails to predict many fundamental aspects of corporate law because it assumes that the only economic problem to be solved is the problem of getting directors and executives to do what shareholders want them to do. ${ }^{42}$ Yet corporate law may to a very great extent be driven by the need to solve a different problem: the problem of encouraging essential specific investments in projects where contracting is incomplete because the project is complex, long-lived, and uncertain.

Corporations tend to be formed to pursue businesses that require large amounts of enterprise-specific assets, meaning assets that cannot be withdrawn from the enterprise without destroying much of their value. Specific assets can take a large variety of forms. For example, “sunk-cost” investments in research, development, and business processes and relationshipsmoney or time that has already been spent in the hope of earning future profits and is now "water over the dam”- - are specific. So are specialized machines and equipment that cannot be easily converted for other uses. Executives’ and employees’ acquisition of knowledge, skills, and relationships uniquely useful to their present firm, and of little value to other potential employers, are investments in firm-specific "human capital.” Developing customer loyalty, a trusted brand name, or a unique business process are all examples of specific investment. Specific investment poses unique contracting problems. To understand why, consider the case of a group of investors who pool their money and intellectual talents to develop a cancer

\footnotetext{
has also emphasized the importance of director governance for public firms, although for different reasons. See Stephen M. Bainbridge, Director Primacy: The Means and Ends of Corporate Governance, 97 Nw. U. L. Rev. 547 (2003).

42 See Margaret M. Blair, Human Capital and Theories of the Firm, in Margaret M. Blair \& Mark Roe, Employees and Corporate Governance 71 (1999)(discussing asymmetry of canonical principal-agent problem). See also Paul Milgrom \& John Roberts, Economics, Organizations, and Management 334-335 (discussing problem of getting employers to reveal accurate information so that employee incentive contracts can be enforced against them). Legal scholars rarely address the problem of mutual opportunism outside the close corporation context. See, e.g., Eric Talley, Taking the "I” out of “Team”: Intra-Firm Monitoring and the Content of Fiduciary Duties, 24 J. Corp. L. 1001, 1015-21 (1999); Edward B. Rock \& Michael Wachter, Waiting for the Omelet to Set: Match-Specific Investments and Minority Oppression in Close Corporations, 24 J. Corp. L. 913, 914-15 (1999).
} 
treatment. Once the money is spent and the research begun, the investors' time and money has been transformed into an intellectual asset that, at least until it is patented and gets Food and Drug Administration approval, is largely specific to the enterprise. Neither the bottles and petrie dishes in the lab, nor the lab notes, nor the records of the biologists and physicians who tested the treatment would have much value if not used by the company to get the patent and the FDA approval, and to manufacture and sell the drug. The investors get the greatest value from their investment by keeping their resources together until they can bring the whole project to fruition.

As a result, each of the investors must worry that if the business is formed as a traditional partnership—if there is no entity status and no capital-lock in—all of the investors are vulnerable to the possibility that the group might not hold together long enough to see the project through to its finish. Alternatively, and just as threatening, any one investor who provides a critical resource would be in a position to opportunistically threaten to withdraw his or her interest in order to coerce the others into giving up a larger share of any gains that flow from the joint project. Co-investors who contribute to projects requiring large amounts of specific investment accordingly can find themselves at risk from each other and from each others' successors and creditors. Unless the risks are controlled, the project may not be pursued in the first place. This is where the new scholarship suggests that the creation of an incorporated legal entity with board governance can be useful.43 If the investors form a corporation and take shares of stock in exchange for their contributions, the money that financial investors have put up, along with the scientists' work-in-progress and any patents obtained, belong to the corporate entity. The financiers cannot unilaterally withdraw their funding, nor can the entrepreneurs and

43. See, e.g., Blair, Locking In, supra note 41 at 391("The creation of a separate legal entity allows business organizers to partition the assets used in the business. ... [This means ? participants and third parties are assured that the pool of assets used in the business will be available to meet the needs of the business first (such as, to pay the claims of the business's creditors) before these assets can be distributed to shareholders."); Blair \& Stout, Team Production, supra note 41at 292 ("the firm can hold title to the property, and can thereby function as the repository of all 'residual' income from team production that is not actually paid out to team members.") 
employees unilaterally extract the value of their time and effort (much less their lab notes and intellectual contributions) unless such a break-up and liquidation of the firm is agreeable to the corporation's board of directors. The board in turn cannot be controlled by any one of the participants alone. All of the participants in the venture have to some degree "tied their own hands" and made it harder to withdraw.44 This seemingly self-defeating arrangement can in fact be self-serving if it encourages profitable joint investment in projects that require specific investments that could not otherwise be protected.

The problem of encouraging specific investment when corporate production requires different individuals to contribute different types of resources, such as a project that requires an executive's time, an entrepreneur' idea, and an investor's money, is often described as one of “team production.” Building on the work of economists Armen Alchian and Harold Demsetz, ${ }^{45}$ we define "team production” as "production in which 1) several types of resources are used . . .2) the product is not a sum of separable outputs of each cooperating resource ... [and] 3) not all resources used in team production belong to one person.”46 Team production presents obvious problems of coordination and shirking, problems addressed by Alchian and Demsetz ${ }^{47}$ and by

44. See, e.g., Stout, supra note 19, at 669 ("for some reason, participants in public corporations-including investors - value director primacy. Just as the legendary Ulysses served his own interests by binding himself to the mast of his ship, investors may be serving their own interests by binding themselves to boards"). Of course, this analysis does not apply to corporations that have a single shareholder. However, most corporations of any significant size have multiple shareholders, even when those shareholders may be relatively few in number.

${ }^{45}$ See Armen Alchian \& Harold Demsetz, Production, Information Costs, and Economic Organization, 62 Am. Econ. Rev. 777 (1972). Other scholars who have done important work on this idea include Bengt Holmstrom, Moral Hazard in Teams, 13 Bell J. Econ. 324 (1982); Oliver Hart, Incomplete Contracts and the Theory of the Firm, 4, J. L. Econ. \& Org. 119 (1988); Sanford Grossman \& Oliver Hart, The Costs and Benefits of Ownership: A Theory of Vertical and Lateral Integration, 94 J. Pol. Econ. 691, 693 (1986); Oliver Hart, An Economist's Perspective on the Theory of the Firm, 89 Colum. L. Rev. 1757 (1989); Oliver Hart \& John Moore, Property Rights and the Nature of the Firm, 98 J. Pol. Econ., 1119 (1990); Raghuram C. Rajan \& Luigi Zingales, Power in the Theory of the Firm, 113 Q.J. Econ. 387 (1998).

46 Alchian \& Demsetz, supra note 45, at 779.

47 Id. at 781. 
Holmstrom $^{48}$ in early work proposing solutions that echo typical solutions to the principal-agent problem.

Then Oliver Hart and some coauthors began to look at the issue. ${ }^{49}$ Although they did not use the language of team production, they considered a similar problem, and added an important additional confounding condition-the team members must make investments specific to the enterprise, putting them at risk if the enterprise failed or one team member attempted to hold up the others. Hart et al's addition may be vital to understanding corporations, because corporate production often requires a variety of "stakeholder” groups to make specific investments that cannot be protected by formal contracts and that put them at risk if the business fails or they are forced to sever their relationship with the firm. Consider the executive who works long hours at a start-up company for below-market wages, or the customer who becomes adept at using a particular corporation's products, or the community that builds roads and schools to serve a company’s factory employees.

Once again, however, the solution proposed by Hart et. al. echoed the principal-agent model: at least one team member must have “ownership” or “property rights” over the team’s joint output, meaning a residual right of control. This proposed solution was admittedly flawed: while such a property right would protect the team member who owned it, assigning the right to only one member of the team left the other members vulnerable. Hart et. al. suggested this might be an inevitable difficulty with specific investment in team production, and that the best that

\footnotetext{
48 Holmstrom, supra note 45, noted that ex ante agreements about the division of a surplus from production would give team members incentives to shirk and free ride on the efforts of fellow team members, while attempts to divide up the surplus ex post would lead to costly rent-seeking behavior. His proposed solution involved giving any surplus to an outsider not on the team unless the surplus was large enough to ensure that no team member had shirked. Such a solution provides perverse incentives to the outsider to undermine the contract by bribing a team member to shirk. For a more complete discussion of the development of theoretical work in economics on team production, see Blair \& Stout, Team Production, supra note 41 at 265 -279.

${ }^{49}$ See sources cited supra note 45 .
} 
could be done would be to assign the property right to the team member whose enterprisespecific investment was most “important" in some sense. ${ }^{50}$

Rajan and Zingales then proposed an alternative solution. They noted that under Hart's solution, not only would team members who do not "own” a right to the team's output have reduced incentives to make specific investments, but the owner might sometimes have a stronger incentive to opportunistically sell his control over the other team members (thereby capturing the value of any specific investments they had made) instead of completing the team and making specific investments himself. Their proposed solution to this problem was that all team members might be better off if they yielded control rights to an outsider. ${ }^{51}$ In a detailed discussion elsewhere, we have expanded upon the Rajan and Zingales solution and suggested it provides a rationale for why people might choose to organize production through a corporation with entity status governed by a board of directors. ${ }^{52}$

In brief, forming a corporation requires the participants in that corporation to yield decision-making power over their ability to earn a return on their specific investments to a board of directors that is not, itself, a residual claimant in the firm. ${ }^{53}$ Corporate participants yield power over their specific investments in the sense that, if they choose to withdraw from the firm, they must leave those investments behind or see their value destroyed. And as long as they stay with the firm, they cannot directly control how their (or other team members') specific assets are used, nor can they demand that the corporation pay for the value of those specific investments.

\footnotetext{
50 See Hart \& Moore, supra note 45, at 1149 ("[A]n agent is more likely to own an asset if his action is sensitive to whether he has access to the asset and is important in the generation of the surplus.”)

51 See Rajan \& Zingales, supra note 45, at 422 ("[I]f all the parties involved in production (i.e. including the entrepreneur) have to make substantial specific investments over time, it may be optimal for a completely unrelated third party to own the assets. ... [T]he third party holds power so that the agents critical to production do not use the power of ownership against each other”).

52 See Blair \& Stout, Team Production, supra note 41 at 276-287; see also Blair \& Stout, Director Accountability, supra note 41.

53 Blair \& Stout, Team Production, supra note 41 at 274-277.
} 
As a result, the only way corporate participants can profit from specific investment in the company is by continuing their relationship with the corporate "team" and hoping the board allocates to them some portion of the surplus generated by team production. Since the board is not itself a residual claimant and its members are precluded by fiduciary duties from expropriating the surplus for themselves (at least in their roles as directors), the board has no incentive to opportunistically threaten the value of team members' specific investment. And since the board at a minimum wants the team to stay together and to stay productive (thus assuring the continuation of the members' board positions), the board has some incentive to do this.

Space constraints preclude a full discussion here of how focusing on capital lock-in and specific investment in team production can explain a wide range of important phenomena in the business world, including the development of the corporate form, ${ }^{54}$ the nature of directors' fiduciary duties, ${ }^{55}$ the proper role of corporate counsel, ${ }^{56}$ the rules of derivative suit procedure, ${ }^{57}$ the regulation of takeover bids and antitakeover defenses, ${ }^{58}$ and even bankruptcy reorganization ${ }^{59}$ and the necessity of a corporate-level income tax. ${ }^{60}$ Interested readers are invited to explore the large and growing literature on such topics. Below we simply note how these new intellectual tools promise to help us build a paradigm of corporate law that both explains and predicts the important anomalies discussed in Part I.

\footnotetext{
54 Blair, Lock-In, supra note 41.

55 See Blair \& Stout, Team Production, supra note 41 at 298-308.

56 See Kostant, supra note 41.

57 See Blair \& Stout, Team Production, supra note 41 at 292-97.

58 See Lynn A. Stout, Do Antitakeover Defenses Decrease Shareholder Wealth? The Ex Post/Ex Ante Valuation Problem, 55 Stan. L. Rev. 845 (2002).

59 See LoPucki, supra note 41.

60 See Bank, supra note 41.
} 


\section{A. Directors Are Not Agents But “Mediating Hierarchs" Who Protect Specific Investment in Corporations and Distribute the Returns from That Investment}

Viewing corporations through the lens of capital lock-in and team production offers a variety of insights into the basic nature and structure of corporate law. One of the most important of these insights is an answer to the question of why, as discussed in Part I.A, corporate law does not treat corporate directors as agents who must do the shareholders' bidding but instead grants boards a remarkably wide range of autonomy and control over corporate assets. Board autonomy worsens the agency cost problem in corporations, because it means shareholders (and other stakeholders for that matter) have less leverage to pressure boards to maximize corporate returns. At the same time, both the capital lock-in approach and the team production model suggest that director authority in public corporations remains a "second-best" solution that provides offsetting economic benefits by encouraging and protecting specific investment in corporate production.

For example, capital lock-in theory explains that corporate law does not allow any individual shareholder or subgroup of shareholders to exercise direct control over the board for the simple reason that, if this were allowed, a shareholder with liquidity concerns (for example) could use that control to force the firm to sell essential specific assets at a loss in order to raise the funds necessary to buy out the shareholder's interest. Alternatively, and perhaps even more likely, the shareholder might opportunistically threaten to do this to try to force the other investors to agree to give the opportunist a larger share of corporate earnings. ${ }^{61}$ The need to

\footnotetext{
${ }^{61}$ As this discussion suggests, one can view capital lock-in primarily as a device that protects shareholders from the opportunism of other shareholders. We believe, however, that capital lock-in makes incorporation an attractive way to do business not only because it protects shareholders from each other, but also because it protects the interests of nonshareholder groups that have made specific investments in corporations that cannot be protected by formal contracts. For example, without capital lock-in, shareholders as a class might pressure directors to pay excessive dividends. (Shareholders with diversified portfolios are indifferent to increasing firm leverage, even though increasing risk threatens the interests of creditors, employees, and other corporate participants who cannot diversify their human capital or other specific investments in the company.) From an ex ante perspective, shareholders may
} 
protect the company’s specific assets thus explains why corporate law limits individual shareholders' power to control directors and to demand dividends, share repurchases, or other transactions that would threaten locked-in capital.

Relatedly, team production analysis emphasizes how shareholders' capital must be locked in and controlled by boards not only to protect shareholders' interests, but also to protect the interests of other team members that have made specific investments (e.g., employees, creditors, and customers who may have made past contributions of time and effort, invested in specialized relationships, skills, and loyalties, or acquired knowledge of particular firm processes and products). Shareholders cannot be allowed to directly control corporations because they are only one among the many groups that must yield control rights over the firm's assets and outputs in order to make credible commitments to other team members that they will not hold up the whole team to extract a larger share of the surplus.

Team production analysis accordingly can explain why, under the rules of corporate law, directors are not "agents" of either subgroups of shareholders or shareholders as a class, nor of any other class of investors. Rather, as we have argued in some detail elsewhere, ${ }^{62}$ directors are better described as “mediating hierarchs" who must balance the competing needs and demands of shareholders, creditors, customers, suppliers, executives, rank-and-file, and even the local community, in a fashion that protects specific investments in the corporation and keeps the corporation alive, healthy, and growing. In other words, boards of directors, who alone are empowered to decide how to distribute the corporate surplus, should use this power to ensure

benefit from yielding power over dividends to directors who owe fiduciary duties to the corporation as a whole, because ceding this power enables the shareholders as a group to make a more credible commitment not to strip assets out of the firm prematurely or injudiciously, in turn attracting the important firm specific investments of nonshareholder groups. This analysis can explain why corporate law grants directors the legal authority to ignore even a unanimous shareholder request for dividends.

${ }^{62}$ See Blair \& Stout, Team Production, supra note 41; Blair \& Stout, Director Accountability, supra note 41. 
that every vital team member gets at least enough of the surplus to keep that member motivated to stay with the team.

\section{B. Many Different Groups Make Specific Investments in Corporations And Are Potential Residual Claimants.}

Once one acknowledges the legal reality that directors are not shareholders’ agents, one must also accept that a second key component of the principal-agent model—the idea that shareholders are the sole residual claimants in firms-lacks a solid foundation. When corporate directors enjoy any significant discretion to decide how the corporation uses its assets, it becomes grossly inaccurate as a descriptive matter to assert that shareholders of a public corporation are the sole residual claimants of that firm. ${ }^{63}$ To the contrary, shareholders are only one of many groups that may act as residual claimants or residual risk bearers in the sense that directors have authority to provide those groups with benefits (and sometimes to saddle them with burdens) above and beyond the benefits and burdens described in their formal contracts with the firm. For example, when a corporation is doing spectacularly well, it is common to see employees receive dental benefits and greater job security, executives get nicer offices and access to a company jet, bondholders get increased protection from insolvency, and the local elementary school get charitable donations of money and equipment. Conversely, these groups suffer along with shareholders when times are bad, as employees get stingier benefits, executives fly coach, debtholders face increased risk, pension funds fail, and the elementary school does without.

\footnotetext{
63 See Blair \& Stout, Team Production, supra note 41 at 250 (“Our analysis rests on the observation - generally accepted even by corporate scholars who adhere to the principal-agent model - that shareholders are not the only group that may provide specialized inputs in to corporate production. Executives, rank-and-file employees, and even creditors or the local community may also make essential contributions and have an interest in the enterprise's success” (footnotes omitted).)
} 
Directors in reality simply do not behave the way the principal-agent model predicts they should. They reward many groups with larger slices of the corporate pie when the pie is growing, and spread the loss among many when the pie is shrinking. Far from providing evidence that directors are doing something wrong by imposing "agency costs” on shareholders, this observation suggests directors may be doing exactly what team production analysis says they should be doing—acting as mediating hierarchs who balance the conflicting interests of the many members who make up a healthy, productive corporate team.

\section{The Concept of "Legal Personality" Plays An Important Economic Role in Protecting Specific Investment}

One of the greatest weaknesses of the principal-agent model is its characterization of the firm as a nexus of contracts. As noted earlier, this idea is in tension with the claim that shareholders "own" corporations, since it is difficult to envision how one might own a nexus. A second problem, however, is that the nexus metaphor does not give any guidance on where, exactly, the "firm" begins and ends. If an executive who signs an employment agreement with Microsoft is "in" the firm, what about the closely-held corporation that signs an agreement to supply certain software programs? Are Microsoft and the closely-held supplier one single company? What about the buyer who signs a contract to purchase a Microsoft product? Is the buyer part of Microsoft? Under the nexus approach, it is difficult to see where Microsoft ends and the rest of the world begins.

The capital lock-in approach may not, by itself tell us what "a firm” is, but it at least provides a way to define what "a corporation" is. In brief, a corporation is a legal entity that can own property in its own name. This concept has economic as well as legal importance. As noted in the previous section, entity status allows a corporation to lock in resources so they can 
be converted safely to specific assets. Although one might imagine other legal mechanisms for achieving capital lock-in—say, a trust arrangement ${ }^{64}$ - incorporation accomplishes the same result cleanly and simply.

Indeed, team production analysis suggests incorporation does more. By placing ownership of the firm's assets in the hands of the firm itself rather than in the hands of the firm's shareholders, incorporation encourages specific investments from other important groups that often participate in corporate production, including creditors, executives, customers, and rankand-file employees. These constituencies become more willing to invest because they know that control over the corporation--and with it, control over their specific investments—now rests in the hands of a board, and not in the hands of shareholders who might opportunistically threaten to destroy their investment or exclude them from the firm in order to demand a larger share of any surplus. The result is a mutual "hand's tying" arrangement among the various groups that make specific investments in corporations, an arrangement that ultimately works to benefit all. This arrangement would be undermined by allowing any one of the team members to exercise direct control over the firm's assets.

Focusing on the problem of specific investment rather than the problem of agency costs accordingly allows us to see why corporate "personhood” matters so much. Legal personality worsens agency costs. As Clark’s treatise puts it, from a shareholder’s perspective “a major problem with legal personality as it has been developed for public corporations has been presented by the 'hard to kill' character of the corporation.." ${ }^{, 5}$ At the same time, this

\footnotetext{
${ }^{64}$ Joint stock companies used by business people in the eighteenth and nineteenth centuries before the corporate form was widely accessible sometimes used complicated trust arrangements to hold the assets used in the enterprise. This approach did not always achieve its intended purpose, as courts tended to treat such arrangements as a species of partnership and they would be broken up if a "member" died or wanted out. See Blair, Lock-In, supra note 41 at 421-23 and sources cited therein.

${ }^{65}$ Clark, supra note 4, at 762.
} 
Frankenstein’s monster aspect of incorporation may perform a vital economic function by protecting the value of shareholders' and other team members' specific interests in corporate production. To quote again from Clark's treatise, legal personality can "safeguard going concern values. „66

\section{Corporate Law Leaves Corporate Purpose Open To Protect Directors' Role As Mediating Hierarchs}

What does this all this imply for the fourth anomaly noted in this essay — the open-ended nature of the legal rules regarding corporate purpose? Interestingly, here capital lock in and team production analysis give somewhat different, although in some respects complementary, answers.

The capital lock-in function of corporate law helps protect what Clark's treatise calls "going concern” value for all corporate participants, not just shareholders. But capital lock-in theory, by itself, it doesn't necessarily preclude a legal stance that emphasizes shareholder value maximization as the appropriate corporate goal. The team production approach, however, offers another and in many ways more intriguing explanation for the anomaly of open-ended corporate purpose. In brief, it suggests that the appropriate normative goal for a board of directors is to build and protect the wealth-creating potential of the entire corporate team—-wealth" that is reflected not only in dividends and share appreciation for shareholders, but also in reduced risk for creditors, better health benefits for employees, promotional opportunities and perks for executives, better product support for customers, and good "corporate citizenship" in the

${ }^{66}$ Id. 
community. ${ }^{67}$ To accomplish this, directors must have a wide range of discretion to balance competing interests in a way that keeps the team together and keeps it productive.

Team production analysis consequently warns against defining corporate purpose in a narrow fashion that would allow one or more members of the corporate team to challenge the boards' authority and argue either that the board is pursuing the wrong goal, or that it is pursuing the right goal the wrong way. Once we leave behind the narrow objective of maximizing share value, it is impossible for an outsider like a court to design an algorithm to measure whether a board is maximizing returns to the corporate team, and dangerous to invite courts to try. Allowing either shareholders or other stakeholders to claim in court that directors who are not violating their loyalty duties by using their corporate powers to enrich themselves are nevertheless acting with an "improper purpose” simply invites corporate participants to try to extract wealth from other team members by waving the stick of personal liability over the directors’ heads.

A corollary is that the corporate desideratum associated with the principal-agent model“increase share value whether this helps or harms other team members"-is a recipe for inefficiency. The team production approach undermines the principal-agent model's claim that corporations are governed well when they are governed in a fashion that maximizes share value. Rather, good governance means making sure the corporation survives and thrives as a productive, value-creating team--even though this is an objective that is difficult to measure, much less maximize.

\footnotetext{
67 See, e.g., Blair, supra note 29 at 239 ("Management and boards of directors should understand their jobs to be maximizing the total wealth-creating potential of the enterprises they direct"); Blair \& Stout, Team Production, supra note 41 at 271 (arguing that primary function of mediating hierarch is to exercise control "in a fashion that maximizes the joint welfare of the team as a whole" (emphasis in original).
} 
It is important to note that the idea that corporate law does not require directors to maximize share value in no way implies that shareholders are worse off under corporate law rules that give directors such open-ended discretion. Team production analysis teaches that equity investors as a class are better off when corporate participants, including equity investors, lenders, employees, and entrepreneurs, have an organizational form available to them that allows them to cede power over corporate assets to the kind of director governance system provided by corporate law. Without director governance, these groups might not be able to overcome the risks of mutual rent-seeking created by complex, uncertain, and long-lived projects, and so might not pursue profitable projects in the first place.

Past and present business experience support this hypothesis. Nineteenth century American business history is a story of entrepreneurs going to state legislatures in increasing numbers to seek permission to form corporations_corporations that outside investors purchased shares in and outside creditors loaned money to. The increasing popularity of this practice, even when it was much simpler and less costly to use partnership law to organize businesses, suggests that both the entrepreneurs, and the creditors and equity investors who financed their projects, found the arrangement valuable. ${ }^{68}$

Today we have even better evidence that incorporation and board governance serves the interests of shareholders and other corporate participants-evidence that was not available to scholars writing in the 1980s and even early 1990s. In brief, U.S. corporate law is mostly “default rules,” meaning that incorporators can modify the basic rules of corporate law by putting customized provisions in the corporate charter before the company "goes public" and

\footnotetext{
68 See Blair, Lock In, supra note 41; see also Margaret M. Blair, Reforming Corporate Governance, 1 Berkeley Bus.L.J. 1, 3 (2004) ("the decision of a firm's organizers to choose one organizational form or another, given the wide array of legal form choices available, should be taken as a signal that the organizers wanted the features of the form they choose . . . . In particular, . . . in choosing the corporate form, organizers opt into a series of rules and a body of law . . . that yields important decision rights to corporate directors.”)
} 
sells shares to outside investors. ${ }^{69}$ If investors really wanted more power over boards, there is no reason why an enterprising entrepreneur who wanted to appeal to this desire could not add a charter provision that, for example, prohibited the board from adopting a "poison pill” that would allow them to reject a premium takeover bid the shareholders favored. Similarly, if outside investors really believed that requiring boards to pursue share value would make them better off, incorporators could put "shareholder wealth maximization" in the charter as the corporate purpose.

Public corporation charters virtually never contain such provisions. ${ }^{70}$ Even more telling, recent empirical studies demonstrate that when promoters do tinker with charter provisions in the pre-IPO stage — exactly the stage in which they most need to appeal to outside investors — they almost always move in the opposite direction, adding provisions like a staggered board structure that insulates directors from shareholder influence even more than the default rules of corporate law already do. ${ }^{71}$ Outside investors happily buy shares in these firms. This pattern strongly suggests that director discretion, including the discretion that comes from open-ended rules of corporate purpose, serves the long-run interests of "the investor class" even if it works against the interests of particular shareholders in particular firms at particular times. Capital lock in and team production help explain why.

\section{Conclusion}

\footnotetext{
69 See, e.g., Del. Code Ann. Tit. 8, Section 102(b)(3)(granting incorporators power to add charter provisions including "any provision for the management of the business and for the conduct of the affairs of the corporation, and any provision creating, defining, limiting and regulating the powers of the corporation, the directors, and the stockholders....”)

70 Stout, supra note 19 , at 699.

71 Id. at ns. 73, 74 (citing studies). An even more extreme if anecdotal example can be found in the case of the recent Google IPO, in which Google issued stock with reduced voting rights to public investors. The shares sold readily and appreciated in value despite the lack of control rights. See Lynn A. Stout \& Iman Anabtawi, Sometimes Democracy Isn’t Desirable, Wall. St. J. at B2 (August 10, 2004)(discussing Google IPO).
} 
For most of the past three decades, U.S. corporate law scholarship has been dominated by a single, widely accepted paradigm: the principal-agent paradigm. Yet U.S. corporate law itself refuses, in many puzzling ways, to follow the precepts of the principal-agent model. These puzzling departures include such important anomalies as director governance; shareholder powerlessness to demand dividends; the importance of legal personality; and the open-ended rules of corporate purpose.

Nevertheless, until recently, many corporate scholars have chosen to continue to embrace the principal-agent approach for the simple reason that they lacked a compelling alternative. The result has been a literature that emphasized the agency cost problem and especially how director governance creates conflicts of interest between shareholders and directors, and that tended to be blind to the problem of specific investment and how director governance may temper potential conflicts between and among shareholders, executives, creditors, and others who make specific investments in corporations.

Today the situation has changed dramatically. Although the principal-agent model still has great influence, corporate scholars are involved in an escalating debate over the best way to understand the modern public corporation. ${ }^{72}$ This debate increasingly recognizes the legal reality that public corporations are governed by boards and not by shareholders. It also recognizes recent developments in economic theory that teach that, in addition to the problem of agency costs, corporate production can raise important problems of encouraging specific investment.

These insights have inspired contemporary legal and economic scholars to explore new and different approaches to understanding the rules of corporate law. In this essay we have briefly touched upon two of these emerging alternative paradigms: the capital lock-in approach,

${ }^{72}$ See, e.g., sources cited supra note 41. 
and the team production model. In exploring these alternatives, we are not suggesting that the original principal-agent model is always useless and should be discarded. For some corporate problems the principal-agent approach may be just as useful as the capital lock-in or team production approach, and considerably easier to apply. Similarly, Newtonian theory is just as useful as (and considerably easier to apply than) Einstein’s theory of relativity for many problems in physics. Nevertheless, there are important phenomena in physics that can only be explained and predicted using Einstein’s approach. And there are likewise important—indeed fundamental—phenomena in corporate law and practice the principal-agent model simply cannot account for.

In accord with Kuhn's thesis, these anomalies have attracted the attention of a new generation of corporate scholars. Rather than trying to minimize or ignore the poor fit between the principal-agent model and the rules of corporate law, they have instead sought to develop new models. They have been aided both by new theoretical tools, and by new empirical findings, that highlight the essential role specific investment can play in determining corporate structure. In the process, they are working toward new visions of the corporate purpose that go beyond the simple rubric of shareholder wealth. 